\title{
An Empirical Research of Foreign Trade and Economic Growth in Chongqing
}

\author{
Zongrong Ran \\ College of Economics and Management \\ Southwest University \\ Chongqing, China \\ ran0@swu.edu.cn
}

\begin{abstract}
After Chongqing became the municipality of China, Chongqing kept the high speed of annual average of $16 \%$ or more to develop. And it has highlighted a positive effect of the region's economic growth. For the depth study of the size that foreign trade can boost the economic growth in Chongqing, sorting out the major variables affecting the positive pulling effect, and then proposing further strategies to Chongqing to promote the coordinated development of economic trade and local economic, this paper select some related statistic data from 1987 to 2012 in Chongqing and has an empirical research of the relationship between external trade and economic growth from a quantitative level. By the research, the pulling effect which the external trade has on the economic growth in Chongqing is visible increasingly. If Chongqing wants to achieve the goal of building the open highland in the western inland, it has to strengthen the reinforcement of the external trade to the economic growth, boost technological creation skills in the whole foreign trade enterprises, optimize the product structure, build international brands, and vigorously implement the strategy of "going out".
\end{abstract}

Keywords- foreign trade; economic growth; coordination analysis; countermeasure; strategies

\section{INTRODUCTION}

Since Chongqing became a municipality of China, it has developed a lot in its foreign trade and social economy, and the GDP increased from 136.024 billion Yuan in 1997 to 652.872 billion Yuan in 2009. The Gross National Product of the first half year of 2012 was 530.719 billion Yuan, with the average annual growth rate of $14 \%$, leading Chongqing one of the top cities in the west in terms of economic growth. Meanwhile, the actual volume of foreign trade in Chongqing raised from 13.914 billion in 1997 to 52.675 billion in 2009, with reference to customs statistics, the volume of import and export of Chongqing's foreign trade is 53.2 billion dollars in 2012 , added by $82.2 \%$ which ranks the second across the country, including 38.57 billion dollars of export with a rise of $94.5 \%$ and 14.63 billion dollars of import with the increase of $56.1 \%$. The pulling that effect the external trade has on the economic growth in Chongqing becomes visible gradually. This paper selects some related statistic data from 1987 to 2012 in Chongqing and has an empirical research of the relationship between external trade and economic growth from a quantitative aspect.

\section{LITERATURES REVIEW}

The relationship between foreign trade and economic growth has always been a hot issue in the study of western development economics.

The main stream can be classified into three types in the area of qualitative study: the first is the so-called mainstream the people who put forward that there is a positive relationship between foreign trade and economic growth namely foreign trade can stimulate economic growth. Representative economist D. H. Robertson and R. Knox hold this theoretical perspective, and they think the external trade is "the Engine of growth", and foreign trade can not only bring direct and static benefits, but also the indirect and dynamic ones. While Raul Prebisch and H. W. Singer have the opposite view that the international division of labor should be taken into consideration, as for the primary product exporting countries, the foreign trade cannot drive the economy, and may even lead to increasing poverty. The third is the neutral point represented by Kravis who always believed that "foreign trade is only handmaiden of growth", not "engine of growth".

In quantitative research, Chinese and foreign scholars have their own opinions. The main research results of Western scholars (1) embodied in international (regional) comparative study. BelaBalassa (1978) concluded that exports act an important role in promoting economic growth, by analyzing the annual data from 1960 to 1973 of 11 semi-industrialized countries and using correlation analysis and OLS regression test analysis; RubinaVobra (2001) got the summary that exports have an positive and important pulling effect on economic growth while weak in low-income countries by using regression analysis methods that analyze the yearly data of five Asian countries: India, Pakistan, the Philippines, Malaysia and Thailand-from 1973 to 1993. (2) Embodied in longitudinal study of single country. Ghatak (1998) remarks that exports may not lead to economic growth, resulting from the VAR model analysis of South Korea's annual data on the five variables: per capita investment, government support, money supply, interest and exchange rate, but on the other hand, however admits that there is a long-term equilibrium relationship between export and economic growth, and export growth will drive the economic growth after adopting the coordination analysis, VECM model, and Granger causality test. Abhijit and Theodore (2005) insist on that no long-term 
equilibrium relationship exists between India's export, import and economic growth, and export growth cannot bring a significant increase in economic growth, because of some analysis, such as recognize $\mathrm{R}$ model, coordination analysis, Granger causality test and impulse response, on the India's inter-annual data from 1991 to 2001.

The majority of researches support the view that there is a high correlation between foreign trade and economic growth, while some disagreements still exists on conclusions. Some scholars believe that the effect of exports on economic growth is conditional and may play a different role in a different country or region or different stages of development of the country or region (Laszlo (2006)).

Below is the table of the study list from domestic scholars.

TABLE I. MAJOR RESEARCH LITERATURE ON THE RELATION BETWEEN FOREIGN TRADE AND ECONOMIC GROWTH (2005-2010)

\begin{tabular}{|c|c|c|c|}
\hline Author & Period & Method & Conclusion \\
\hline $\begin{array}{l}\text { Yu Jian } \\
(2005)\end{array}$ & $\begin{array}{l}1978- \\
2003\end{array}$ & $\begin{array}{c}\text { Correlation and } \\
\text { Regression Analysis }\end{array}$ & $\begin{array}{l}\text { Foreign trade is the } \\
\text { engine of China's } \\
\text { economic growth. }\end{array}$ \\
\hline $\begin{array}{l}\text { Hu Bing } \\
\text { ( } 2006 \text { ) }\end{array}$ & $\begin{array}{l}1978- \\
2003\end{array}$ & $\begin{array}{l}\text { LA-VAR model, Granger } \\
\text { causality test, Impulse } \\
\text { response function }\end{array}$ & $\begin{array}{l}\text { No Granger causality test } \\
\text { exists between foreign } \\
\text { trade and economic } \\
\text { growth. }\end{array}$ \\
\hline $\begin{array}{c}\text { Yao Shu-jie } \\
\text { (2007) }\end{array}$ & $\begin{array}{l}1978- \\
2000\end{array}$ & $\begin{array}{l}\text { Panel unit root test, } \\
\text { Dynamic panel data } \\
\text { estimation techniques }\end{array}$ & $\begin{array}{l}\text { Exports and FDI has a } \\
\text { positive and significant } \\
\text { contribution on China's } \\
\text { economic growth. }\end{array}$ \\
\hline $\begin{array}{l}\text { Lu Ming- } \\
\text { hui } \\
\text { ( } 2008 \text { ) }\end{array}$ & $\begin{array}{l}1978- \\
2006\end{array}$ & Granger causality test & $\begin{array}{l}\text { The effect of foreign } \\
\text { trade on economic } \\
\text { growth is not obvious, } \\
\text { conversely, positive. }\end{array}$ \\
\hline $\begin{array}{l}\text { Fu Shao- } \\
\text { jun } \\
\text { ( } 2009 \text { ) }\end{array}$ & $\begin{array}{l}1981- \\
2006\end{array}$ & $\begin{array}{c}\text { Panel coordination } \\
\text { methods }\end{array}$ & $\begin{array}{l}\text { Foreign trade plays a role } \\
\text { in promoting economic } \\
\text { growth. }\end{array}$ \\
\hline $\begin{array}{l}\text { Chen Yan } \\
\text { (2010) }\end{array}$ & $\begin{array}{l}1981- \\
2008\end{array}$ & OLS regression model & $\begin{array}{l}\text { Foreign trade has a } \\
\text { significant impact on } \\
\text { economic growth. }\end{array}$ \\
\hline
\end{tabular}

Showed in Table I, the quantitative researches on the relation between foreign trade and economy can be divided into three categories: First one is called correlation analysis which is to determine the relation between foreign trade and economic growth by correlation coefficient and to measure the degree of influence through the value of correlation coefficient; Second is a regression analysis to establish a linear regression model; The last is coordination analysis that is to decide whether there is a coordination relationship, or a causal relation, or the form of causal relation between the variables by coordination analysis, Granger causality test, impulse response and other methods. Scholars come to various conclusions resulting from selecting different sample interval, adopting different methods and some other reasons. Most analysis focus on single relation just between foreign trade volume, import volume or export volume and economic growth, not on combination with qualitative analysis, and may not take variables, like structural changes of the modes of trade, market structure and so on, into consideration.

There is no doubt that the researches of both Chinese and foreign scholars described previously, have an important implication on this study. This paper will have an empirical analysis on the relation between foreign trade and economic growth by analyzing Chongqing's authoritative statistics from 1987 to 2011.

\section{THE DEVELOPMENT STATUS AND CHARACTERISTICS OF CHONGQING'S FOREIGN TRADE AND ECONOMIC GROWTH}

Since becoming the municipality of China, Chongqing has witnessed rapid growth of foreign trade scale, the increasingly optimizing structure of import and export commodity, diversified trade mode, and diversified market structure, and now is forming a new inland open foreign trade pattern.

\section{A. Upward Tendency of Foreign Trade Volume Yearly}

Since the implementation of Reform and Opening up policy, Chongqing's foreign trade has developed rapidly, and the overall scale of foreign trade stated a rising trend. In 1987, Chongqing's foreign trade volume was only 2.968 billion dollars which is almost the least across the country, while the volume reached 292.17 billion dollars in 2012, including 198.38 billion of export and 93.8 billion of import. All the volume of Chongqing's foreign trade, export and import has increased steadily. In 2012, the volume of Chongqing's foreign trade is 53.2 billion dollars, added by $82.2 \%$ which ranks the second across the country (after Tibet), with annual growth rate of $16.9 \%$, including 38.57 billion dollars of export with an rise of $94.5 \%$ and 14.63 billion dollars of import with an rise of $56.1 \%$, and Chongqing's volume had already taken up more than $3 \%$ shares of the country's total volume. It can be seen from Fig. 1 (below) that Chongqing has became the open highland in the western inland with the rapid development of foreign trade.

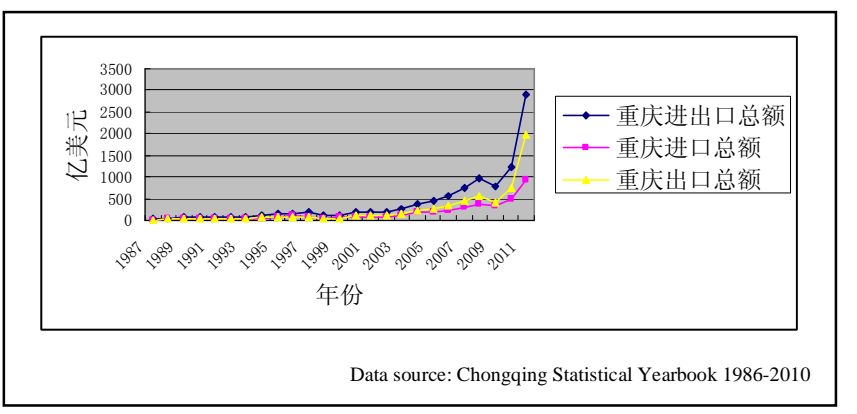

FIGURE1.CHONGQING'S FOREIGN TRADE VOLUME 


\section{B. Growingly Rational Foreign Trade Commodity Structure}

Since 1998, Chongqing's export commodity structure presented little change in a steady state. The proportion of primary products that was $11 \%$ in 1998, showed a declining tendency except for that in 1999, and the decline lasted for a decade, and then the proportion stopped at about $3 \%$ after 2008. In the meanwhile the proportion of manufactured products presented an upward trend (except for 1999 and 2008), and stabilized at about $96 \%$ until 2008. Among the products, the proportion of labor-intensive products decreased with fluctuation, while the proportion of capital-intensive products advanced steadily; in 1999 the latter exceeded the former and became the important part of the manufactured products. According to these statistics, Chongqing's export commodity structure basically achieved a transformation from dominated by single primary products to manufactured, from dominated by labor-intensive products to capital-intensive, and the whole structure upgraded (Fig. 2).

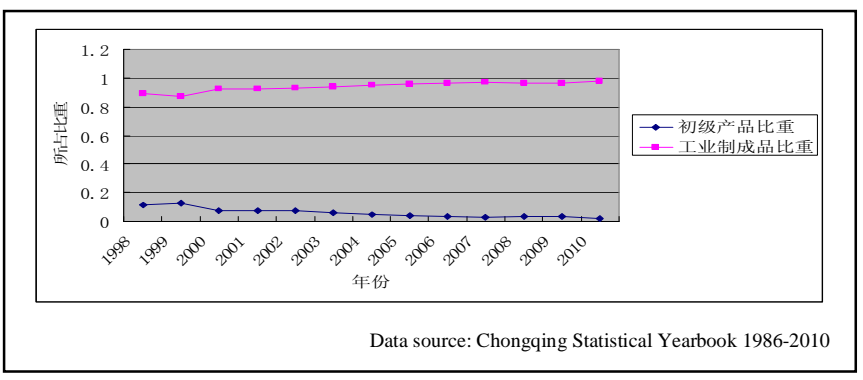

FIGURE2.CHONGQING'S EXPORT COMMODITY STRUCTURE

\section{Diversified Development Trend of Foreign Trade}

In recent years, the development of export trade and import trade of Chongqing appeared different trends. General trade, a form of export trade, the proportion of which continued to fall from $94.23 \%$ in 2001 to $46.55 \%$ in 2011 , became the main form in Chongqing; and processing trade showed the same trend, and both the trends made it clear that there was adjustment of Chongqing's foreign trade structure. As for import trade, the proportion of general trade presented a general upward trend which rose from $62.93 \%$ in 1998 to $87.37 \%$ in 2010 , while the proportion of processing trade had a opposite performance which declined from $36.30 \%$ in 1998 to $8.7 \%$ in 2010 . It can be seen from the table II, general trade is the main form of Chongqing's export trade, and processing trade is developing, while import trade is dominated by general trade. In brief, the overall scale of processing trade, which continued to expand, with rising proportion and rapid development, gradually became the main part of the Chongqing trade (Table II).
TABLE II. Form AND STRUCTURE OF CHONGQING'S ForEIGN TRADE

\begin{tabular}{|c|c|c|c|c|c|c|}
\hline \multirow{2}{*}{ Year } & \multicolumn{3}{|c|}{ Export (\%) } & \multicolumn{3}{c|}{ Import (\%) } \\
\cline { 2 - 7 } & $\begin{array}{c}\text { General } \\
\text { Trade }\end{array}$ & $\begin{array}{c}\text { Processing } \\
\text { Trade }\end{array}$ & Others & $\begin{array}{c}\text { General } \\
\text { Trade }\end{array}$ & $\begin{array}{c}\text { Processing } \\
\text { Trade }\end{array}$ & Others \\
\hline 2005 & $88.66 \%$ & $11.24 \%$ & $0.10 \%$ & $80.55 \%$ & $17.36 \%$ & $2.09 \%$ \\
\hline 2006 & $89.84 \%$ & $10.04 \%$ & $0.12 \%$ & $80.61 \%$ & $17.54 \%$ & $1.84 \%$ \\
\hline 2007 & $88.68 \%$ & $9.08 \%$ & $2.24 \%$ & $80.40 \%$ & $17.19 \%$ & $2.41 \%$ \\
\hline 2008 & $89.31 \%$ & $10.11 \%$ & $0.58 \%$ & $80.39 \%$ & $14.91 \%$ & $4.70 \%$ \\
\hline 2009 & $85.11 \%$ & $13.55 \%$ & $1.34 \%$ & $91.05 \%$ & $6.54 \%$ & $2.41 \%$ \\
\hline 2010 & $78.28 \%$ & $16.03 \%$ & $5.69 \%$ & $87.37 \%$ & $8.70 \%$ & $3.93 \%$ \\
\hline 2011 & $46.55 \%$ & $31.09 \%$ & $22.36 \%$ & $59.20 \%$ & $7.94 \%$ & 32.86 \\
\hline
\end{tabular}

Data source: Chongqing Statistical Yearbook 1986-2011

\section{Transfer to Developed Countries and Regions in Europe} and North America

Originated from relevant statistical data, Asia is still the major market of Chongqing foreign trade. The share of Asia volume to Chongqing's foreign trade volume maintains above $40 \%$ with the highest reaching $67 \%$. The second largest markets are among Europe and North America, and the share is rising steadily these years and keeps fluctuating around 20\% in Europe; while the share in North American has risen steadily to $17 \%$ from 1999 to 2005, and has stabilized at around $15 \%$ in 2010. At the same time, the share in Africa, Latin America and Oceania market generally showed a rising trend.

\section{AN EMPIRICAL RESEARCH OF FOREIGN TRADE AND ECONOMIC GROWTH IN CHONGQING}

\section{A. Sources and Pretreatment of Data}

The Basic data of this study originates from Chongqing Statistical Yearbook (1987-2011), and the index like export total (EX), import total (IN) reflects the development of China's foreign trade, as well as the one of GDP reflects the degree of economic growth. Besides, the volume of Export and Import are calculated by unit of hundred million respectively at the average exchange rate of the period, and GDP by the figure from Chongqing's statistical Yearbook. In order to avoid the dramatic change of data sequences, the treatment of logarithm processing of the three groups data respectively, namely LnGDP, LnEX, LnIM, can eliminate heteroskedasticity of the three variables, and makes the change trend of variable linearization, without change the coordination relation among the variables. From 1987 to 2011(See fig. 3 and fig. 4), Chongqing's GDP entered into a constant growth phase with annual growth rate at above $10 \%$, at the same time period, the Export entered the same phase due to Chongqing's Opening up policy and the Export-oriented economic strategy. So does the Import. 


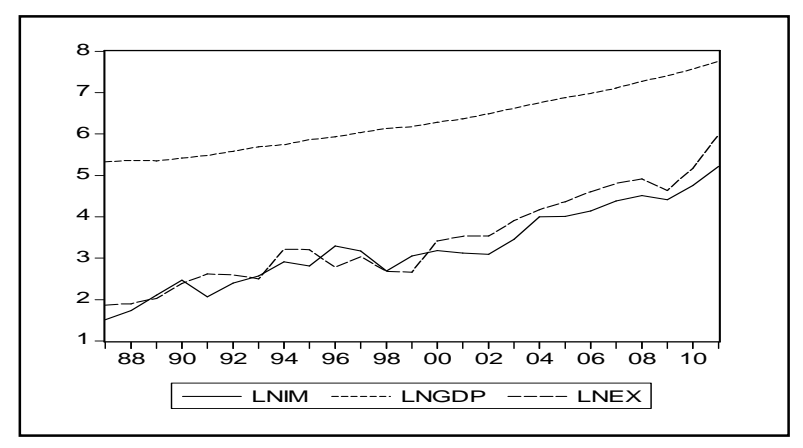

FIGURE3.LOGARITHMIC TIME SERIES OF GDP, IM AND EX

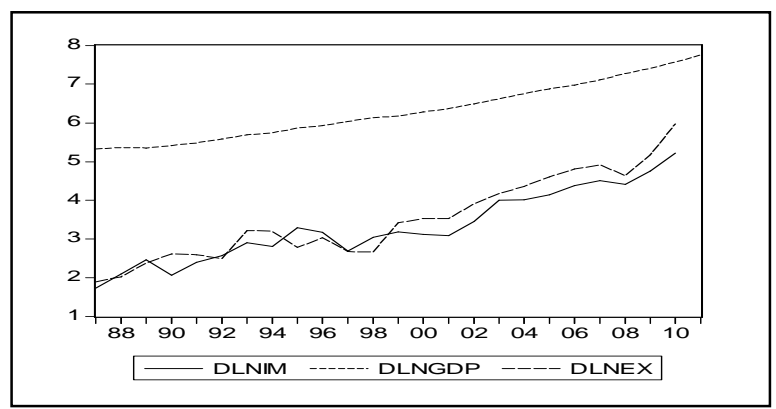

FIGURE4.FIRST DIFFERENCE TIME SERIES OF LOGARITHM OF GDP, IM AND EX

\section{B. Empirical Study on Foreign Trade and GDP}

\section{1) Time series stationary test $-A D F$}

Time series stationary, refers to the statistical rule of time sequence does not vary with the change of time. If the variable Yt has smooth first difference, then Yt has a unit root, and this variable test is known as the unit root test, namely, if all the variables are characterized by a smooth first difference, it proved that there is a coordination relationship between variables. This chapter examines the stationary of economic variables and first difference of each time series by ADF test, and determines the lag during processing by the standard Schwarz information criterion, and table III displays the relevant results.

The conclusion can be drawn from Table III that time series signs no stationary without difference, and becomes stationary after first difference, so series LnGDP, LnEX, LnIM are all integrated of 1 series. According to these results, all the variables such as Export, Import and GDP are integrated of 1 series (I (1)), and the following coordination test is on this basis.

TABLE III. ADF TEST STATISTIC (1987-2011)

\begin{tabular}{|c|c|c|c|c|c|c|}
\hline Variables & ADF Test Statistic & ADF Critical Value (1\%) & ADF Critical Value (5\%) & ADF Critical Value (10\%) & $\begin{array}{l}\text { Forms } \\
(\boldsymbol{c}, \boldsymbol{t}, \boldsymbol{k})\end{array}$ & Conclusion \\
\hline LnGDP & 6.142002 & -3.737853 & -2.9919 & -2.6355 & $\mathrm{c}, \mathrm{t}, 1$ & Unstable \\
\hline LnEX & 0.506298 & -3.737853 & -2.9919 & -2.6355 & $\mathrm{c}, \mathrm{t}, 1$ & Unstable \\
\hline LnIM & -0.295405 & -3.737853 & -2.9919 & -2.6355 & $\mathrm{c}, \mathrm{t}, 1$ & Unstable \\
\hline$\triangle$ LnGDP & -9.223209 & -3.769597 & -3.004861 & -2.6422 & $\mathrm{C}, 0,2$ & Stable \\
\hline$\triangle$ LnEX & -4.811113 & -3.769597 & -3.0049 & -2.6422 & $\mathrm{C}, 0,1$ & Stable \\
\hline$\triangle$ LnIM & -5.306873 & -3.752946 & -2.9981 & -2.6388 & $\mathrm{C}, 0,1$ & Stable \\
\hline
\end{tabular}

\section{2) The coordination relationship between variables}

Coordination relation is used to measure whether there is a long-term equilibrium relationship between economic variables, that is to say, there is no endogenous mechanism affecting the long-term stability of the relationship between some economic variables in the economic system. If the variable deviates from the long-term equilibrium in a certain period after the disturbance, the equilibrium mechanism will be to adjust to make it back to equilibrium in the next period, i.e. although some time series itself is not stable, certain linear combination of them is stationary. The linear combination curves a long-term and stable relationship between the variables.

Through the above unit root test results, it can be drawn that: LnGDP, LnEX and LnIM are variables of integrated of
1 , and a stable linear combination, including linear trend and constant terms, exists between them, and so well as the corresponding Coordination Function. Therefore, we can carry out coordination test on these three time series in order to decide whether there is a long-term stable ratio relation between them, namely the existence of coordination relation. Meanwhile, in the processing, with reference to the unconstrained residual analysis of VAR model, set the optimal lag of the model as lag 3 order, and choose the model of the coordination equation with intercept and time trend of model for the most suitable coordination model, and below are the test results (Table IV). 
TABLE IV. JOHANSEN COORDINATION TEST RESULT

\begin{tabular}{|c|c|c|c|c|}
\hline Characteristic value & Likelihood ratio statistics & Critical Value (5\%) & Critical Value (1\%) & Null Hypothesis \\
\hline 0.821153 & 49.26540 & 29.68 & 35.65 & $\mathrm{r}=0$ \\
\hline 0.497545 & 16.56214 & 15.41 & 20.04 & $\mathrm{r} \leqq 1$ \\
\hline 0.167600 & 3.485399 & 3.76 & 6.65 & $\mathrm{r} \leqq 2$ \\
\hline
\end{tabular}

The test results indicate (See Table IV): The first likelihood ratio statistics 49.26540 under the $5 \%$ level is greater than the critical value of 29.68, and thus reject the null hypothesis at the critical level of $5 \%$. The second one 16.56214 under the $1 \%$ level is less than the critical value of 20.04, and therefore can not reject the null hypothesis $\mathrm{R} \leq 1$. The Third one 3.485399 under the $5 \%$ level is less than the critical value of 3.76 , so it can reject the null hypothesis $\mathrm{R} \leq 2$. That is to say, there is the only existence of a cointegrating vector at the level of 5\% among the series LnGDP, LnEX and LnIM, and the results fully show the existence of a long-run equilibrium coordination relationship in the system consisting of these variables, then it's about to calculate the following standard coordination vector $(1,-0.874867,-0.308492$, 0.961283 ) by Eviews3, and design the long-term equilibrium relation model.

$$
\text { LNGDP=0.874867LNIM+0.308492LNEX+0.961283 }
$$

$$
\text { (0.10878) }
$$

The figures in brackets under the equation (1) refer to the standard coordination parameter difference, and each parameter has a certain meaning of economic elasticity. Every $1 \%$ increase in Chongqing's Export Volume will bring $0.31 \%$ growth in Chongqing's GDP, and every $1 \%$ increase in Chongqing's Import Volume will bring $0.87 \%$ growth in GDP, Based on the model, both the growth of Export and Import will have a large positive effect on the city's economic growth in the long term, and the output elasticity of imports is greater than that of exports. From a long-term perspective, there are two main reasons why the foreign trade has a positive pulling effect on economic growth: first, the imported products can fill the domestic market supply gap, so as to increase private investment and consumption and improve the structure of investment and consumption; second, imports may bring a technical level upgrade of supply, and optimize the overall supply structure. To a great extent, the development of industrialization is characterized by a constant increase of modern production elements, therefore, import trade, which accelerates the introduction of modern production elements through various ways, promotes the overall development of Chongqing's economy.

\section{3) Error correction model}

Error correction Model (ECM) is one kind of econometric models studying both static and dynamic characteristics of the economic problems. The modeling principal is that the existence of coordination relation means the existence of a long-term stable equilibrium relation between variables, and the long-term stable relation exists as a consequence of continuous adjustment in short-term dynamic process. Thus the error correction term is a suitable mediator that fully reflects the effect of correction mechanism on short-term adjustment. ECM can combine short-term volatility and longterm equilibrium, research deeply correction degree of interyear deviation from equilibrium, and get consistent and valid estimation statistics of correction term. Therefore, if coordination relation exists after test, a correction term can be introduced based on the relation and considered as a dependent variable, then to build an ECM with comprehensive consideration of dependent variables reflecting short-term volatility, so as to determine the speed of correction and interaction between economic variables.

\section{$\triangle \mathrm{LNGDPt}=2.335421+0.800198 \triangle \mathrm{LNEXt}+0.253737 \triangle \mathrm{LNIMt}-0.48973 \mathrm{ECMt}-1$}

$$
\text { (0.13902) (0.14460) }
$$

$$
\mathrm{R}^{2}=0.903, \mathrm{~F}=14.59381
$$

To set up ECM by taking residual series in equation (1) as correction term, and it turns out that: foreign trade plays an active role in promoting economic growth in the short time, and export has a better performance than import. In short time, it's because export can improve the sales by take the advantage of leading role in both domestic and international markets and consequently stimulates expansions of industry and its scale and achieves scale economy, that highlights the relation between export and economic growth. While it's because the large advanced equipments and technology accompanying with import shall improve progress rate of domestic industrial technology and economic technology intensity, and correspondingly lead to climax of a new round of economic development that reveals the pulling effects of import on economic growth.

\section{4) Granger causality test}

The coordination test proves the existence of long-term equilibrium relation between variable, while whether the relation can be consider as causality or not needs further examination. Granger causality test is to solve this kind problem and to determine that one variable is helpful to expect another one, and in the test, attention should be paid to the influence of different lags on results. This paper is to set the optimal lag of the model as lag 3 order by Schwarz info criterion. The results of the test are displayed in Table V. 
TABLE V. GRANGER CAUSALITY TEST BASED ON VAR

\begin{tabular}{|c|c|c|c|c|}
\hline Null Hypothesis & Obs & F-Statistic & Probability & Conclusion \\
\hline LNEX does not Granger Cause LNGDP & 20 & 7.33702 & 0.00399 & Rejection \\
\hline LNGDP does not Granger Cause LNEX & & 0.47858 & 0.70269 & Acceptance \\
\hline LNIM does not Granger Cause LNGDP & 20 & 3.72323 & 0.03937 & Rejection \\
\hline LNGDP does not Granger Cause LNIM & & 2.07895 & 0.15254 & Acceptance \\
\hline LNIM does not Granger Cause LNEX & 20 & 1.15211 & 0.36516 & Acceptance \\
\hline LNEX does not Granger Cause LNIM & & 4.72587 & 0.01924 & Rejection \\
\hline
\end{tabular}

It can be seen from below table V: under the critical level of 5\%, LNGDP does not Granger Cause LIIM or LNEM; however, under the same critical level, both LNEX and LNIM do Granger Cause LNGDP, meanwhile, LNEX to some extend does Granger Cause LNIM. In the test, the lag of 3 years means a long-medium period for economic growth, while demand decides economic growth in short term and product factor level depending on supply matters in long-medium term All in all, foreign trade stimulates growth of Chongqing's economy, especially lager export of value-added high-tech products, and in turn export of such products intrigues the need for foreign products, service, advanced technology and equipments (in terms of increase in import), and further to promote the overall industry structure upgrading and stimulate city's economy.

\section{CONCLUSIONS AND SUGGESTIONS}

Concluded from the researches, Chongqing's external trade has an obvious pulling effect on economic growth. In the short run, $1 \%$ increase of import will bring $0.25373 \%$ growth in GDP, and $1 \%$ increase of export bring $0.8002 \%$ growth in GDP, and export performs better; while in the long run, things change, $1 \%$ increase of import will bring $0.8748 \%$ growth in GDP, and $1 \%$ increase of export bring $0.3084 \%$ growth in GDP, import plays as a more important role. The function of import is generally attributed to that import (especially the import of capital goods) make it faster for Chongqing to approach foreign technology due to static effect (production) and dynamic external effect (technology spillover), and help gain more profits.

Therefore, as for import, Chongqing should take the advantage of old industrial base in southwest, make the most use of preferential policies coming from central authorities, such as building Cuntan and Xiyong duty-free ports and new inland bridge to Europe etc, rely on the superiority of geographic transportation, further develop leading industries like software electronic, automobile, machinery manufacturing, chemical and pharmaceutical, introduce by large advanced technology, equipment, production line and pivotal scarce resources, and improve technology of industrial economy, so as to provide necessary technology for industrial upgrade, erase the resource bottleneck, increase competences of export goods and boost Chongqing's economy. With respect to export, the city should exploit "two markets" and "two resources" of domestic and foreign, introduce advanced technology, strengthen enterprise innovation, build worldclass brands, and take most use of the lager inflows of FDI and abundant talent reserves, and vigorously promote the industrial transformation from labor-intensive to technology-intensive. Besides, diversification strategy is ought to be implemented.

At present, Chongqing's external trade is mainly distributed in the United States, Japan, Germany, Vietnam, Indonesia, Hong Kong, Iran, Taiwan, South Korea, and India, with the highest share in the United States, Japan, and Germany. As problems about international trade friction, international energy, raw materials supply, like oil and iron, issue on Taiwan and demand tension deteriorate; and political risk in external trade is increasing, so market diversification is the urgent choice in such circumstances. In the future, Chongqing should manage to cultivate in emerging markets in the South Asia, the Middle East, Africa, Latin America and Oceania at the same time when continuing to consolidate the traditional market, and gradually form a diversified market structure with focus on emerging markets, with support from neighboring countries and rational distribution of developing and developed countries, so as to reduce the market dependence on certain union states. The choice of export market is to adapt corresponding policies and strategy on basis of actual situation of different countries and regions, and to implement level management, which is to give priority to consolidate the core layer as to build a reliable rear for external trade, and to develop potential layer as to foster new point of trade growth. Only by those, is it possible to reduce the risk and guarantee healthy development of foreign trade, and finally, find an inland open development way in which exports can drive imports, as well as balanced development between them in order to jointly promote regional economic growth.

\section{REFERENCES}

[1] Chongqing Statistical Yearbook 1996-2012

[2] Tyler, Growth and export expansion in developing countries: some empirical evidence, Journal of Development Economics, 1981, pp. 121130.

[3] Xu Lian-he and Lai Ming-yong, An empirical research on exportorientation economic growth: reviews and comments, World Economy, 2002, pp. 43-49.

[4] Li Ming-wu, Research review on foreign trade and economic growth, Academy Forum, 2004, pp. 56-60. 